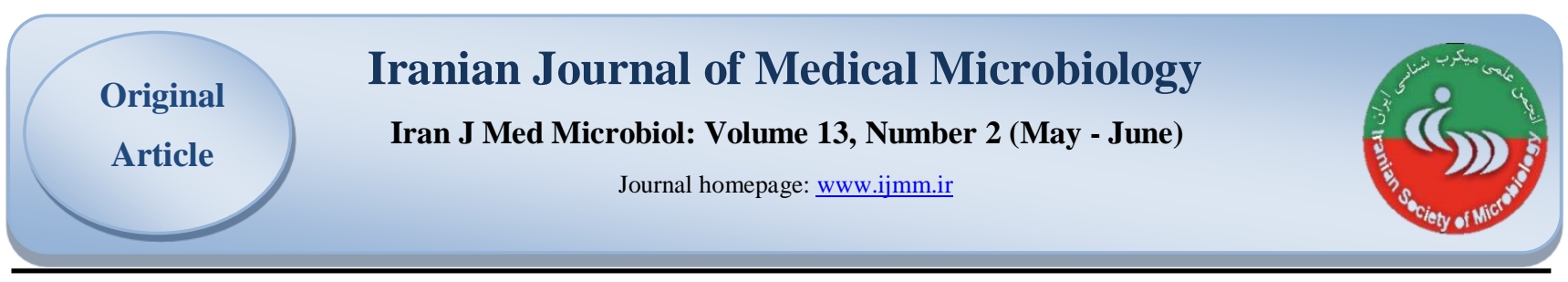

\title{
Antimicrobial Effect of Combined Extract of Three Plants Camellia Sinensis, Teucrium Polium and Piper Nigrum on Antibiotic Resistant Pathogenic Bacteria
}

Fatemeh Masoumipour, Mehdi Hassanshahian, Hosseinali Sasan*, Tayebeh Jafarinasab

Department of Biology, Faculty of Science, Shahid Bahonar University of Kerman, Kerman, Iran

\section{Article Information}

\section{Article Subject: \\ Antibiotic Resistance}

DOI:

\section{Corresponding author:}

\section{Hosseinali Sasan,}

Department of Biology, Faculty of Science, Shahid Bahonar University of Kerman, Kerman, Iran

\section{Email:}

hsasa@uk.ac.ir

Use your device to scan and read the article online

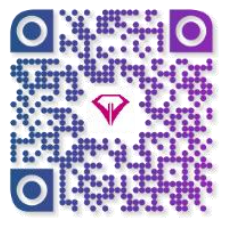

\section{Abstract}

Background and Aims: Microbial biofilms are responsible for $65 \%$ of human infections and antibiotic resistance. Therefore, finding appropriate ways to prevent infection and biofilm formation is essential. Medicinal plants are one of the suitable candidates to inhibit the antibiotics resistance particularly in biofilm forms. In this study, antimicrobial effects of T.C.P combined extracts (methanolic and ethanolic) were evaluated for 6 antibiotic resistant bacteria in planktonic and biofilm forms.

Materials and Methods: The antibacterial activity of extracts on planktonic and biofilm form of antibiotic resistant bacteria, were evaluated by disk diffusion method, macrobroth dilution technique and microtiter plate method.

Results: According to disc diffusion test (MBC and MIC), extracts were efficient for inhibition of planktonic forms of bacteria. Although the ethanolic extract was more effective compared to the methanol extract. The T.C.P combined extracts could inhibit biofilm formation and destruct synthetized biofilms. Inhibitory effects on metabolic activity of bacteria had a direct association with the concentration of extract. The maximum inhibitory effects of T.C.P combined extracts on biofilm formation, destruction of synthetized biofilms and inhibition of metabolic activity were observed for S. aureus, (98.13\%), S. aureus, (96.3\%) and E. coli (81.16\%) respectively.

Conclusion: T.C.P combined extracts can be used as an alternative component with inhibitory antibiotic resistant bacteria in planktonic and biofilm form.

Keywords: Biofilm, Medicinal plants, Antibiotic resistant, Antibacterial activity

Received: 2017/10/09 Accepted: 2019/07/22 Available online: 2019/08/23

Copyright ( $)$ 2019. This is an open-access article distributed under the terms of the Creative Commons Attribution- 4.0 International License which permits Share, copy and redistribution of the material in any medium or format or adapt, remix, transform, and build upon the material for any purpose, even commercially.

How to cite this article:

Masoumipour F, Hassanshahian M, Sasan H, Jafarinasab T. Antimicrobial Effect of Combined Extract of Three Plants Camellia Sinensis, Teucrium Polium and Piper Nigrum on Antibiotic Resistant Pathogenic Bacteria. Iran J Med Microbiol. 2019; 13 (2) :114-124 


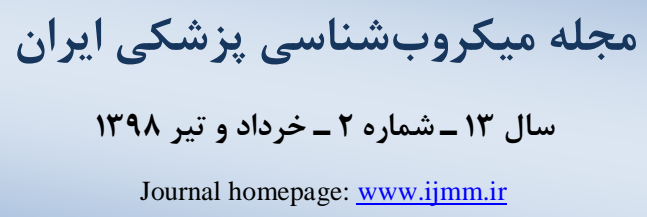

\section{بررسى اثر ضدباكتريايى عصارهُ تركيبى سه كياه كليوره، فلفل سياه و جاى سبز بر باكترىهاى ياتوزن مقاوم به آنتى بيوتيك}

فاطمه معصومى يور، مهرى حسن شاهيان، حسينعلى ساسان"، طيبه جعفرىنسب

كروه زيستشناسى، دانشكده علوم، دانشخاه شهيد باهنر كرمان، كرمان، ايران

\section{جـكيده}

زمينه و هدف: بيوفيلمهاى ميكروبى علت ه 90 درصد از عفونتهاى انسانى و مقاومت آنتىبيوتيكى هستند. بنابراين يافتن

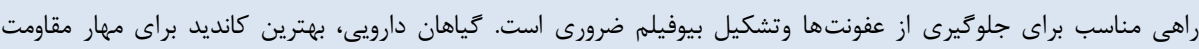

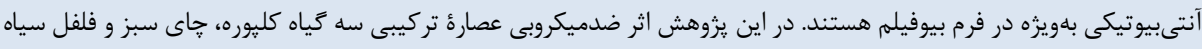
(T.C.P)

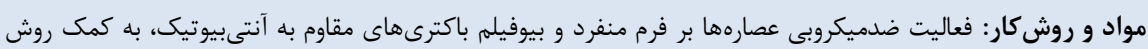

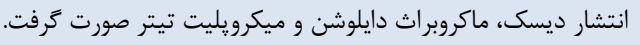

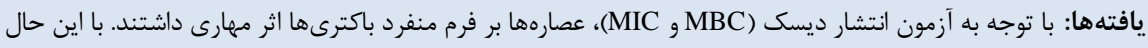

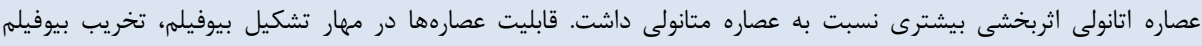

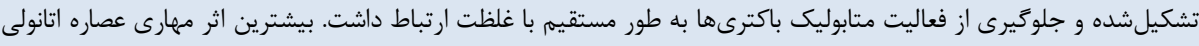

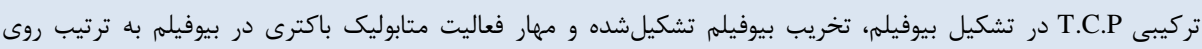

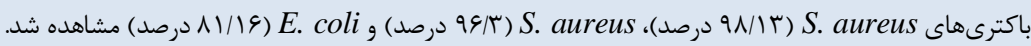

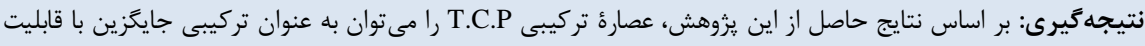

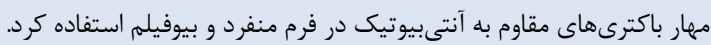
كلمات كليدى: بيوفيله، كياهان دارويى، مقاومت آنتى بيوتيكى، اثر ضدميكروبى

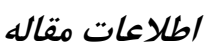

تاريخجهُ مقاله

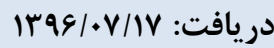

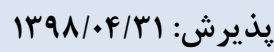

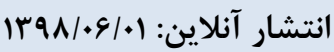

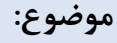

مقاومت پادزيستى (آنتى بيوتيكىى)

IJMM1398;13(2): 114-124

نويسندة مسئول:

حسينعلى ساسان

كروه زيستشناسى، دانشكدة علوم، دانشخاه

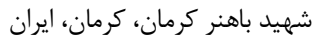

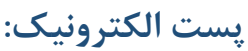
hsasa@uk.ac.ir

كيىرايت (C) مجله ميكروبشناسى بزشكى ايران: دسترسى آزاد؛ كيى بردارى، توزيع و نشر براى استفاده غيرتجارى با ذكر منبع آزاد است.

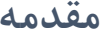

و اين ماتريكس نقش حفاظتى از سلول را در برابر عوامل مختلف بر عهده دارد كه مانع از نفوذ تركيبات ضدميكروبى و عملكرد

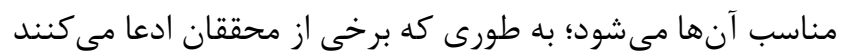

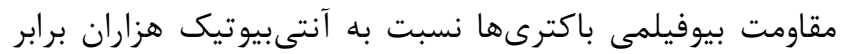

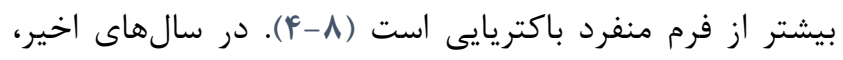

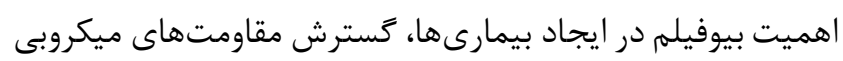
و اثرات جانبى مصرف آنتىبيوتيكها باعث شده است محققان به منظور دستيابى به تركيبات ضدميكروبى جديد، بهويزه در فرم بيوفيلم ميكروبها، از تركيبات طبيعى مانند عصارههاى گياهى

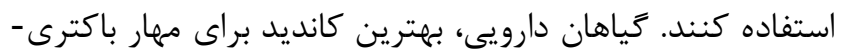
هاى عفونتزاى مقاومت به آنتى بيوتيك هستند كه از مزاياى آن
بيمارىهاى عفونى، بيمارىهاى گسترده و شايع در جهان هستند كه هزينههاى فراوانى را به جوامع بشرى تحميل مى كنند و تهديدى براى سلامت بشر محسوب مىشوند. ميزان مرگ و مير ناشى از اين بيمارىها روزبهروز در جهان، بهخصوص در كشورهاى در حال توسعه رو به افزايش است. يكى از راههاى اصلى درمان

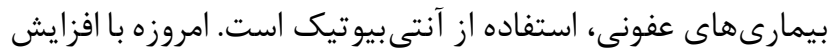

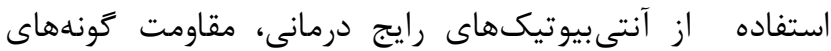
ميكروبى بيمارىزا، در حال شيوع و گسترش روزافزون است (ب(1). يكى از دلايل مقاومت باكترىها تشكيل ساختارهاى بيوفيلمى است كه به معظل شديد عفونتها تبديل شده است. بيوفيله، اجتماعى از سلول هاى ميكروبى است كه با يك ماتريكس خارج سلولى شامل اگزويلى ساكاريد، يروتئين و DNA محصور شدهاند 


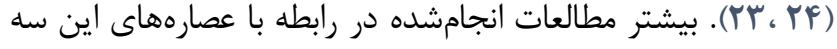

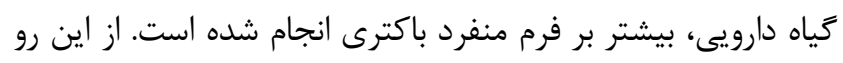

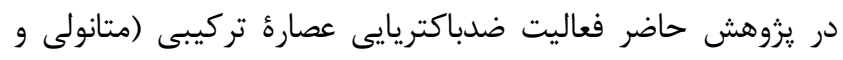

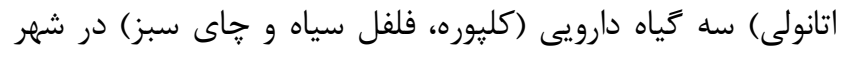

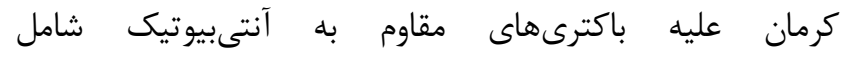
Bacillus cereus ،Pseudomonas aeruginosa ،Escherichia coli Acinetobacter baumannii Staphylococcus aureus، Klebsiella pneumonia

$$
\text { مواد و روشها }
$$

\section{جمع آورى، شناسايى و استخر اج عصاره}

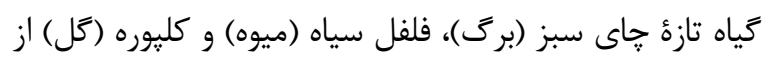

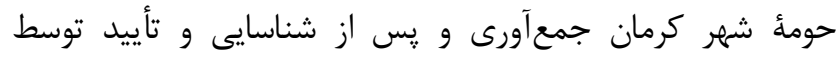

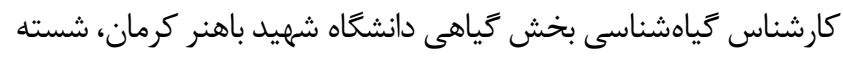

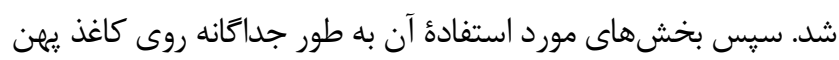

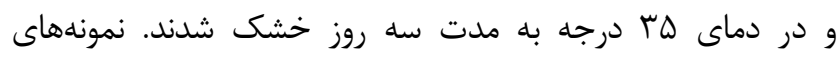

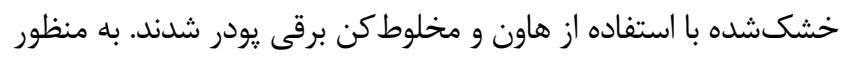

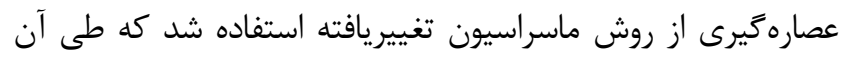

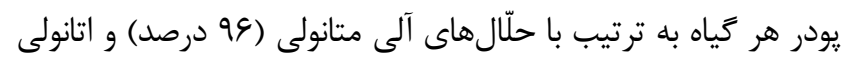

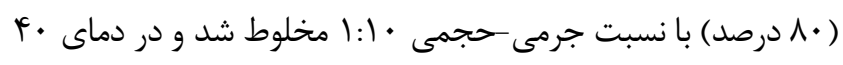

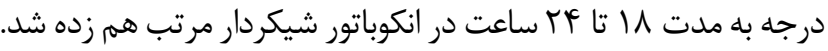

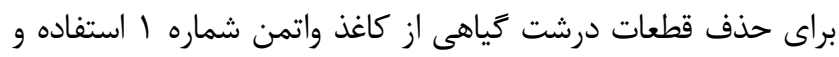

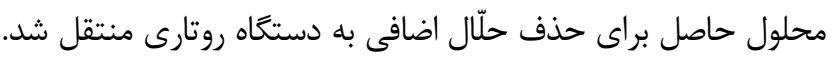

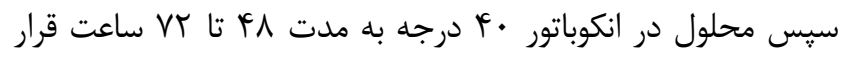

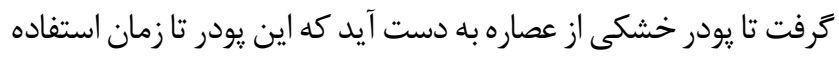

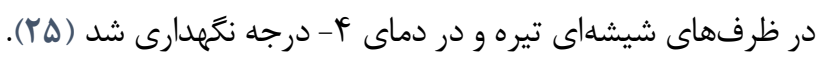

\section{ميكرواركانيسمهاى مطالعهشده و محيط كشت}

در اين يزوهش ب باكترى كرم مثبت (Btaphylococcus aureus

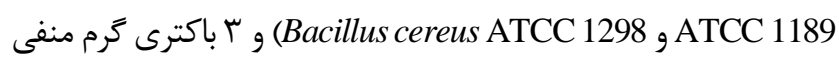
Pseudomonas aeruginosa Escherichia coli ATCC 35218) Acinetobacter baumannii ATCC 1611 ،ATCC 27853 (Klebsiella pneumonia ATCC 700603 ميكروبشناسى دانشخاه علوم يزشكى كرمان تهيه شد. ميكروار كانيسمها

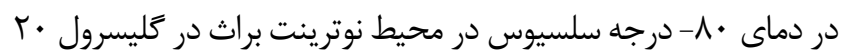

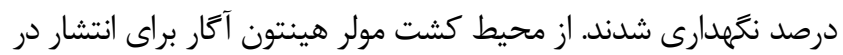
ديسك، MIC و MBC استفاده شد.
مىتوان به كمبودن هزينهُ توليد، عوارض جانبى كم، نداشتن مشكلات زيستمحيطى اشاره كرد (9، ، (Y).

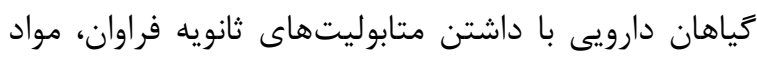

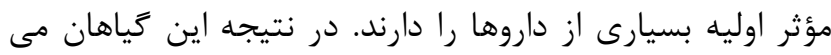

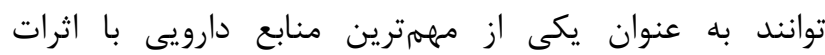

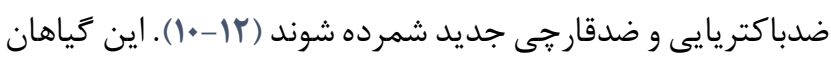

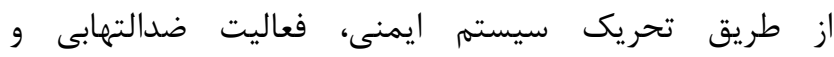
ضداكسيدانى، افزايش هضم و جذب مواد غذايى و فعاليتهاى إيى

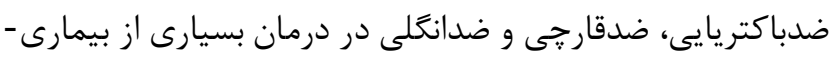

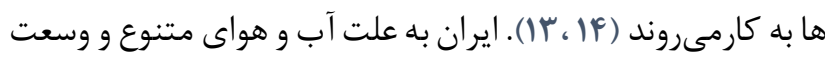

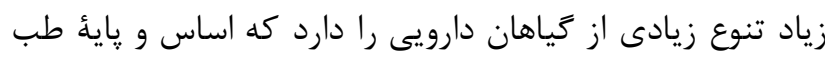
سنتى كشور را تشكيل مى نهد. در اين يزوهش اثر ضدميكروبى سه كياه دارويى شامل كليوره،

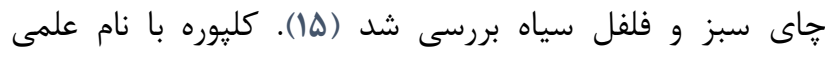

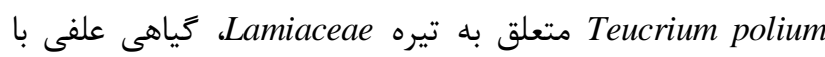

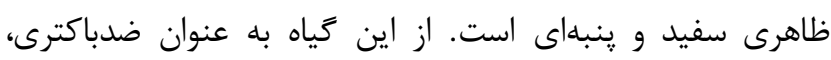

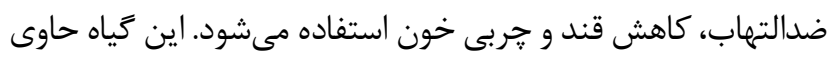
تركيبات زيادى از جمله تانن، ترينوئيد، سايونين، استرول، فلاونوييد

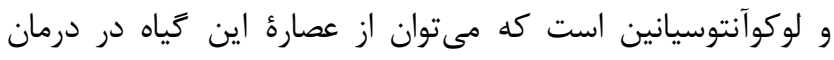
بسيارى از بيمارىها بهره برد (1)-19). بيشتر تركيبات مؤثر اين كياه

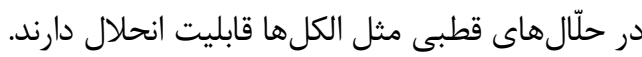

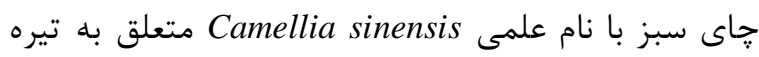
Theaceae

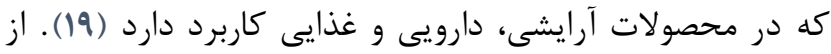

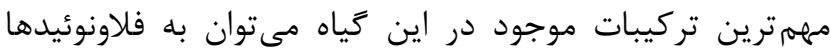

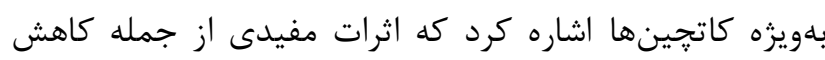
خطرات بيمارىهاى قلبى و عروقى، كاهش بروز بعضى از سرطان -

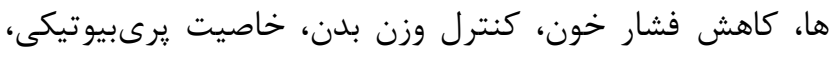

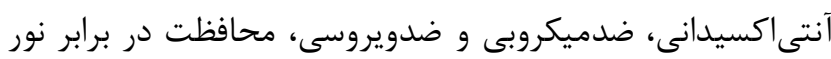

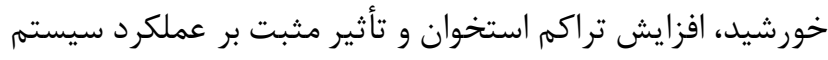

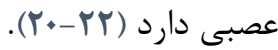

فلفل سياه با نام علمى Piper nigrum متعلق به تيره Piperaceae

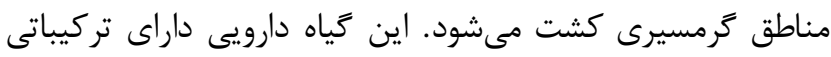

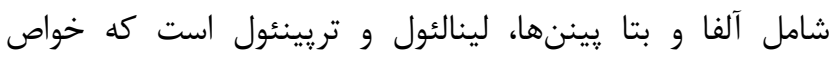

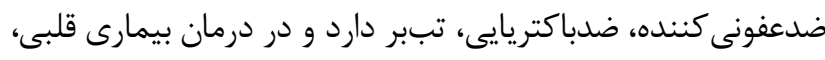

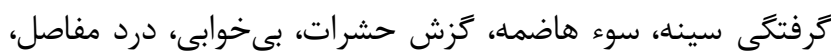

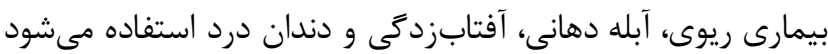




\section{قابليت تشكيل بيوفيلم به وسيلهُ سويهها}

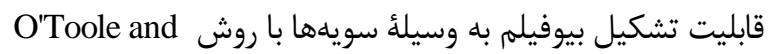

$$
\text { Golter }
$$

\section{قابليت عصاره در ممانعت از تشكيل بيوفيلم}

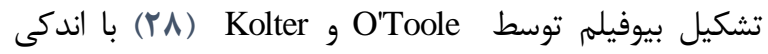

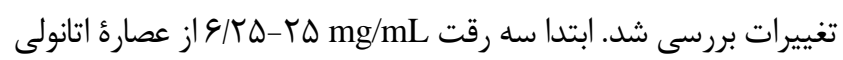

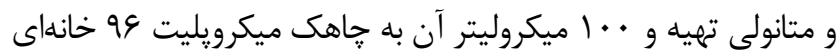

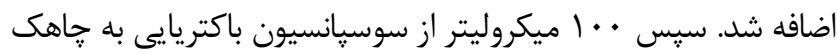

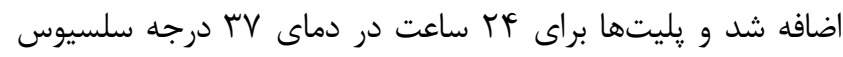

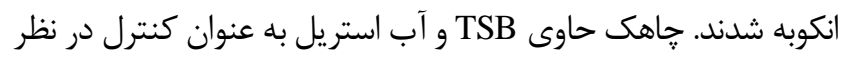
كرفته شد. يس از انكوباسيون ميكروتيتر يليت س مرتبه با بافر فسفات سالين(Phosphate-Buffered Saline (PBS) شسته شد. سيس • 10

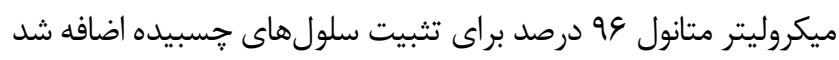

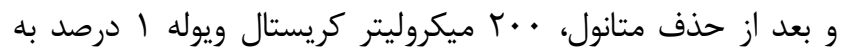

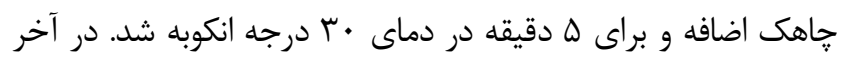

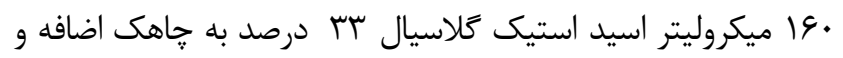
جذب نورى با دستخاه الايزا ريدر (India, Biotec, ELX-800) در طول موج • باع نانومتر خوانده شد.

\section{$\mathrm{M}=100 \times\{(\mathrm{A}-\mathrm{B})-(\mathrm{C}-\mathrm{D}) /(\mathrm{A}-\mathrm{B})\}$}

B درصد مهار تشكيل بيوفيله، A: ميانكين جذب نورى كنترل: M

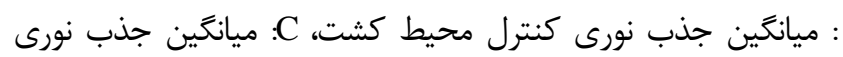

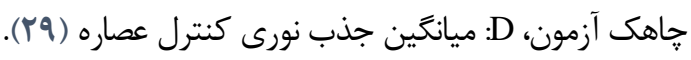

\section{قابليت عصاره در تخريب ساختار هاى بيوفيلمى تشكيلشده} براى تشكيل بيوفيلمها، .ا ميكروليتر از كشتهاى باكتريايى

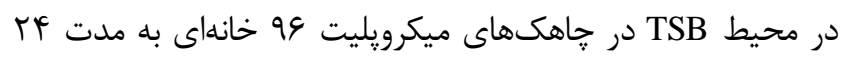

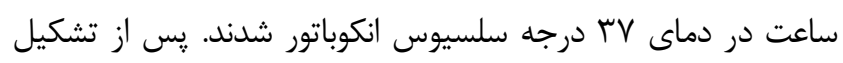

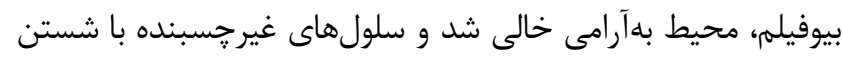

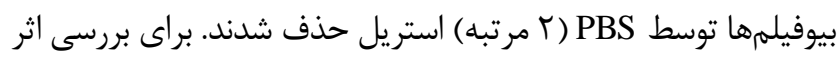

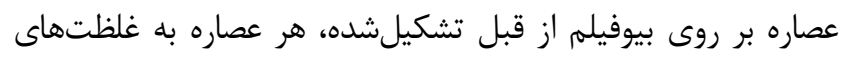

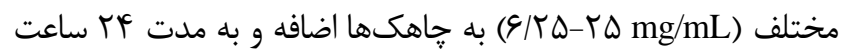
در دماى Vr درجه سلسيوس انكوبه شد. مهار بيوفيلم تشكيلشده با

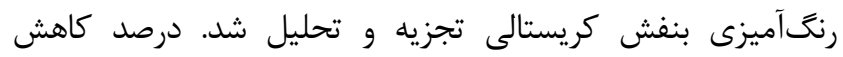

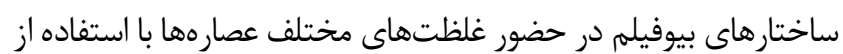

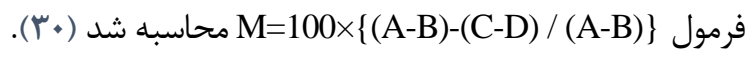

\section{قابليت عصاره بر فعاليت آنزيم دهيدروزناز}

Hoiby

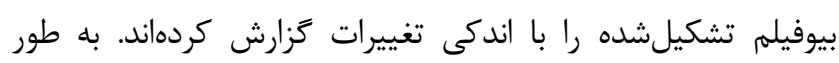

\section{بررسى اثر ضدميكروبى عصارة كَياهى به روش انتشار ديسك}

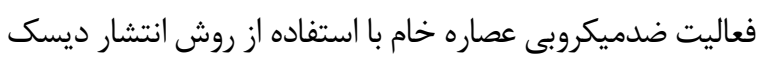
بوئر كربى بررسى شد. به طور خلاصه بعد از كشت يكشبه باكترىها

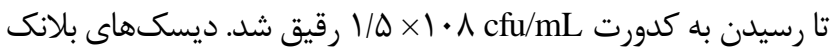

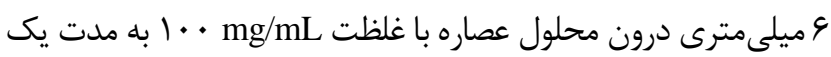

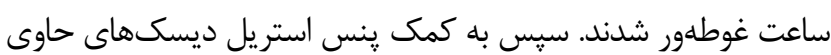

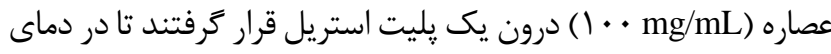
محيط خشك شوند. نحوه سنجش ميزان عصارئ موجود در هر ديسك

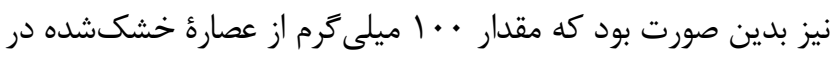

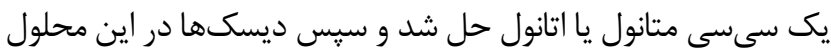

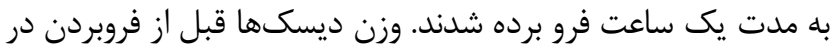

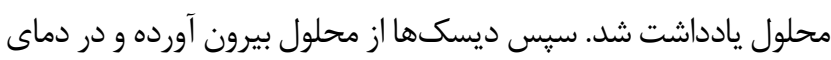
اتاق خشك و دوباره وزن شدند. ميزان جذب عصاره بر اساس اختلاف

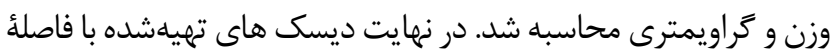

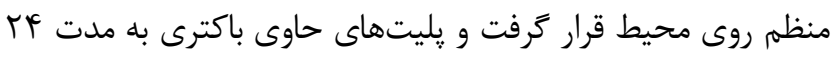

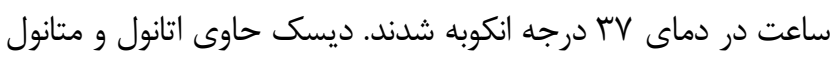
به عنوان كنترل در نظر ترفته شد. قطر هاله عدم رشد ديسكهاي باله

كمك خط كش ميلىمترى اندازمكيرى شد (צ' (؟).

\section{تعيين حداقل غلظت مهارى و حداقل غلظت كشندئى عصاره مقادير MBC و MDC و Mصارة تركيبى T.C.P با روش ماكروبراث}

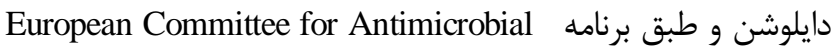
1. انجام شد. در اين روش (EUCAST) Susceptibility Testing رقت از محلول عصاره اتانولى و متانولى با روش رقيقسازى متوالى تهيه

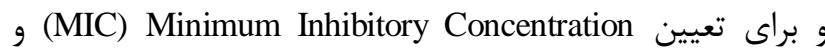
(MBC) Minimum Bactericidal Concentration

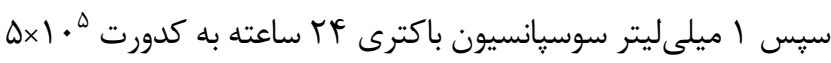
در محيط كشت نوترينت براث به هر رقت ( ا ميلىليتر ) اضافه شد و به به بله

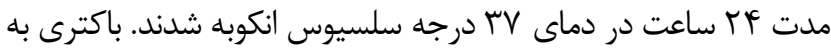

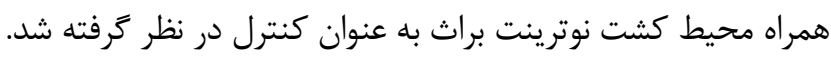

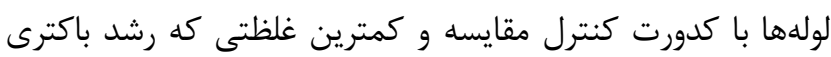
مهارشده داشت، به عنوان MIC در نظر كرفته شد. براى تعين MBC هر يك از عصارهها بدين صورت عمل شد كه رقتهايى از MIC كه

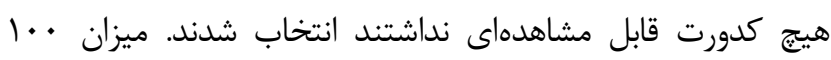
ميكروليتر از اين رقتها روى محيط نوترينت آتار به روش سفرهاى

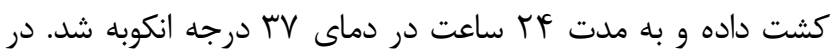

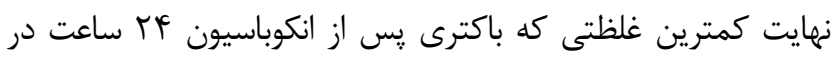

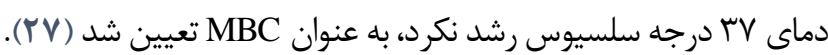


يافتهها

\section{اثراث مهارى عصارة تركيبى در برابر فرم منفرد باكترىهاى}

ميانكَين قطر هاله مهارى، مقادير MIC و MBC عصارئ تركيبى T.C.P باكترى سودوموناس ائروزينوزا بيشترين حساسيت (T)

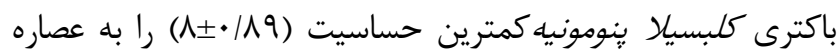

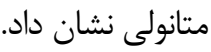
مقادير MIC و MBC براى تركيب T.C.P بر باكترىهاى مطالعهده در محدوده غلظتى MIC براى عصاره متانولى بر باسيلوس سرئوس و سودوموناس ائروزينوزا و

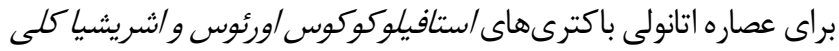

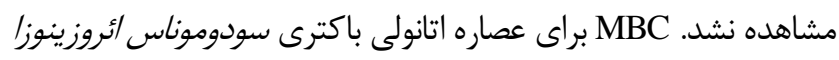

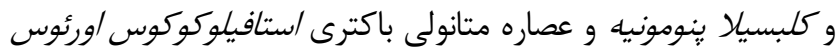

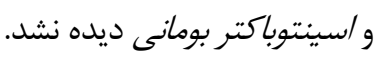

خلاصه، بيوفيلمهاى ساختهشده از قبل ابتدا r مرتبه با PBS شسته شدند، سيس عصاره با غلظتهاى مختلف (

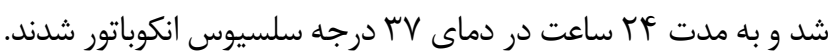
بعد از انكوباسيون،•ه ميكروليتر از محلول ترى فنيل تترازوليوم

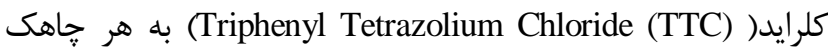

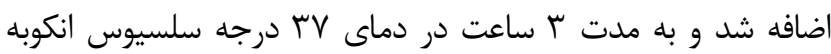

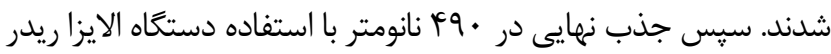
(India , Biotec, ELX-800) درصد كاهش فعاليت متابوليك بيوفيلم در حضور غلظتهاى مختلف دار مانف

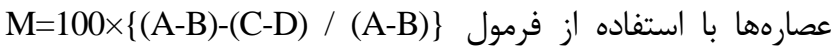

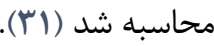

\section{تحليل آمارى يافتهها}

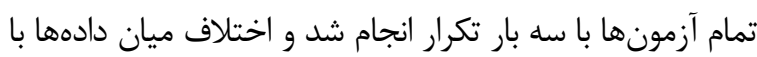
استفاده از تحليل واريانس (ANOVA) و SPSS نسخه ما لبراى ويندوز و در سطح معنى دارى ه • • بررسى شد.

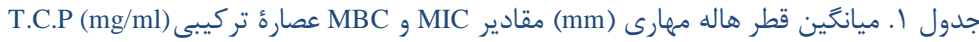

\begin{tabular}{|c|c|c|c|c|c|c|}
\hline \multicolumn{2}{|c|}{ MBC } & \multicolumn{2}{|c|}{ MIC } & \multicolumn{2}{|c|}{ ميانگين土|نحراف معيار } & \multirow{2}{*}{ باكترىها } \\
\hline $\begin{array}{l}\text { عصاره اتانولى } \\
\text { (mg/mL) }\end{array}$ & $\begin{array}{l}\text { عصاره متانولى (mg/mL) } \\
\text { (mg/mL }\end{array}$ & $\begin{array}{l}\text { عصاره اتانولى (mg/mL) } \\
\text { (mg/mL }\end{array}$ & $\begin{array}{l}\text { عصاره متانولى } \\
\text { (mg/mL) }\end{array}$ & $\begin{array}{l}\text { عصاره اتانولى (mg/mL) } \\
\text { (mg/mL }\end{array}$ & $\begin{array}{l}\text { عصاره متانولى } \\
\text { (mg/mL) }\end{array}$ & \\
\hline$r \Delta \pm \cdot / V \varphi$ & · & · & $\Delta \cdot \pm 1 / T r$ & $r \cdot \pm \cdot / V V$ & $9 \pm \cdot / \pi r$ & استافيلوكوكوس /ورئوس \\
\hline$\Delta \cdot \pm \cdot / 9 F$ & $r \Delta \pm \cdot \mid q r$ & $r \Delta \pm \cdot / r T$ & · & $1 \cdot \pm 1 / \cdot r$ & $\mid \Delta \pm \cdot / \Lambda V$ & باسيلوس سرئوس \\
\hline . & $r \Delta \pm 1 / \vee \varphi$ & $\Delta \cdot \pm \cdot / r \Lambda$ & · & $\mid \wedge \pm \cdot / r \Delta$ & $r I \pm 1 / T$ & سودوموناس ائروزينوزا \\
\hline$\Delta \cdot \pm \cdot / \vee \wedge$ & · & $r \Delta \pm \cdot / \Lambda V$ & $r \Delta \pm \cdot / \Lambda r$ & $|r \pm \cdot| q V$ & $11 \pm \cdot / V 9$ & اسينتوباكتر بومانى \\
\hline$\Delta \cdot \pm \cdot / \Delta$ & $\Delta \cdot \pm \cdot \mid \Delta \varphi$ & $\cdot$ & $r \Delta \pm \cdot / \varepsilon r$ & $1 \cdot \pm 1 / 9 \Delta$ & $9 \pm 1 / 4 r$ & ا شريشيا كلى \\
\hline$\cdot$ & $\Delta \cdot \pm \cdot / 9 \varphi$ & $r \Delta \pm ו / T r$ & $r \Delta \pm 1 / \cdot r$ & $\Lambda \pm 1 / \cdot r$ & $\wedge \pm \cdot / \wedge 9$ & كلبسيلا ينومونيه \\
\hline
\end{tabular}

r T m m/mL كمترين اثر مهارى مربوط به همين عصاره با غلظت \&/T mg/mL بر روى سويهى سودوموناس ائروزينوزا ( (9/9 درصد) مشاهده شد. اثر عصاره تركيبى T.C.P بر باكترى هاى مختلف در مهار تشكيل سروزئوريل

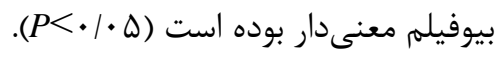

اثرات مهارى عصاره تركيبى T.C.P در برابر تشكيل بيوفيلم قابليت هريك از غلظتهاى مختلف عصاره تركيبى T.C.P بر تشكيل بيوفيلم در شكل ا نشان داده شده است. بر اين اساس

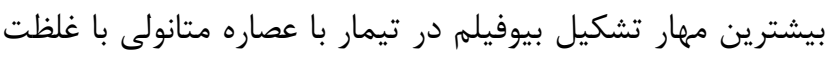




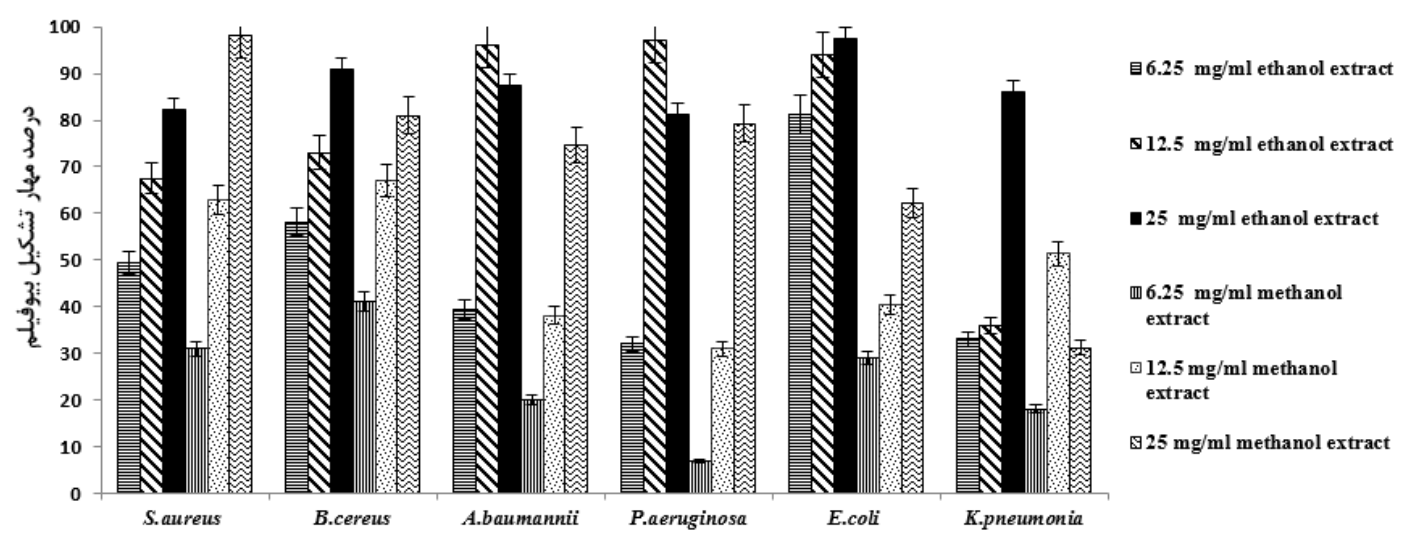

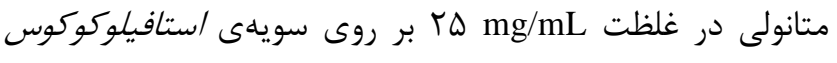

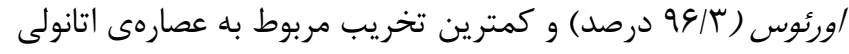

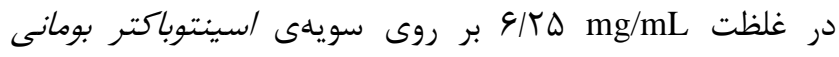

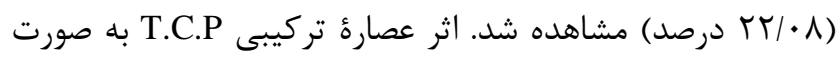

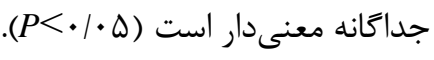

شكل 1. مقايسٔ تأثير عصارة تركيبى T.C.P بر تشكيل بيوفيلهم باكترىها اثرات مهارى عصاره تركيبى در برابر تخريب بيوفيلم تشكيل شده قابليت هريك از غلظتهاى تشاى مختلف عصارههاى تركيبى

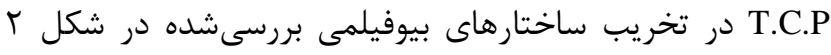

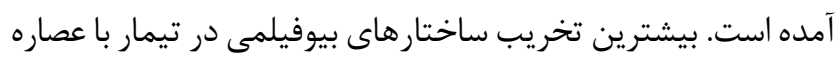

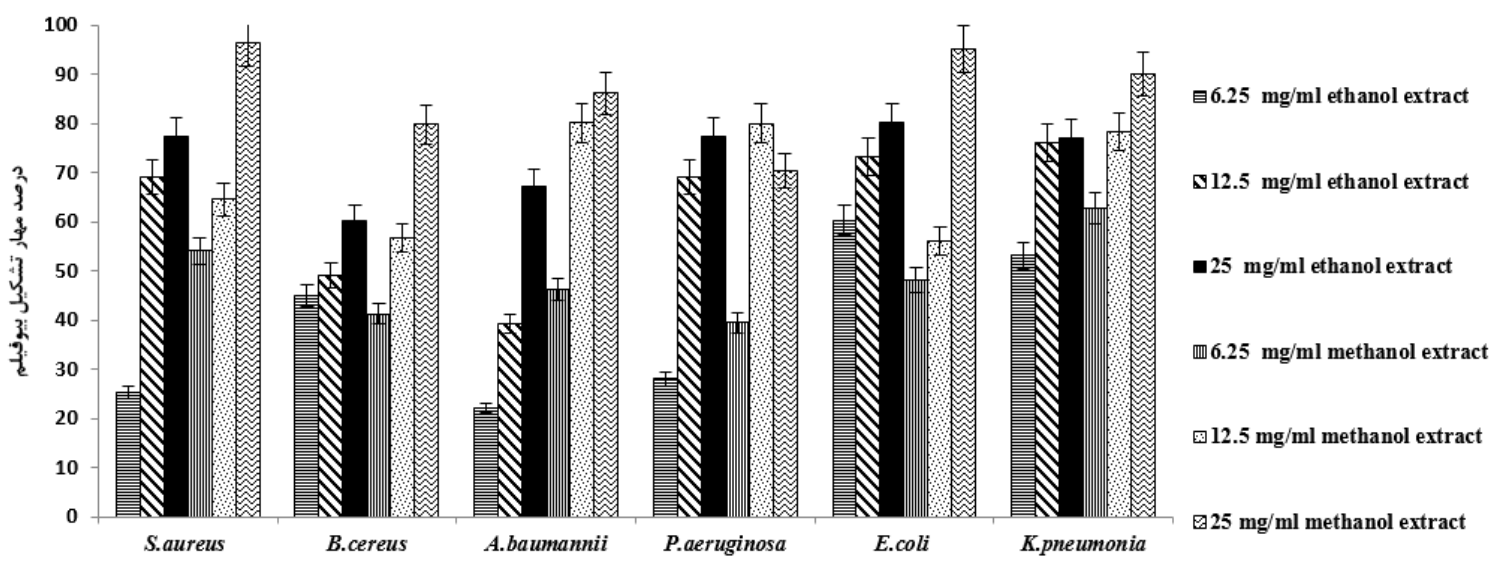

شكل r. مقايسٔ تأثير عصارة تركيبى T.C.P بر بيوفيلم تشكيلشدة باكترىها

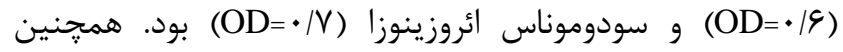

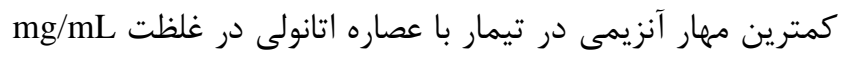

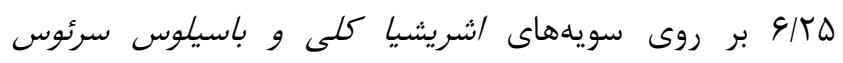
تر وكلبسيلا بنومونيه (OD=1/9)

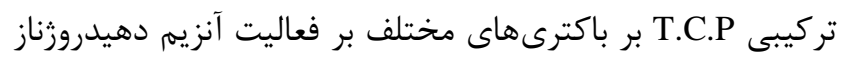

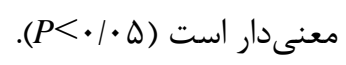

اثرات مههارى عصارهُ تركيبى بر فعاليت آنزيم دهيدروزناز قابليت هريك از غلظتهاى مختلف عصارهى تركيبى T.C.P

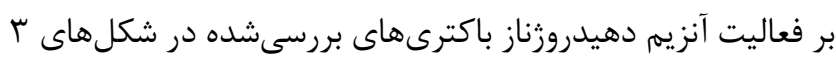

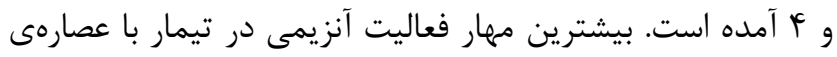

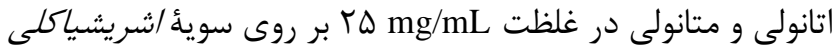




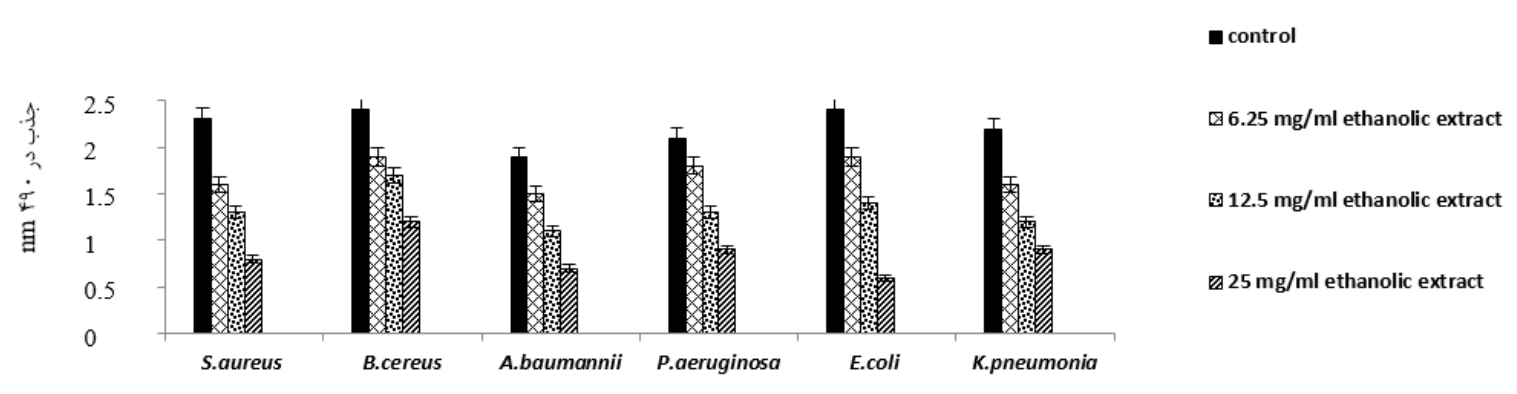

شكل r. مقايسٔ تأثير عصارة اتانولى تركيب T.C.P بر آنزيم دهيدروزناز باكترىها

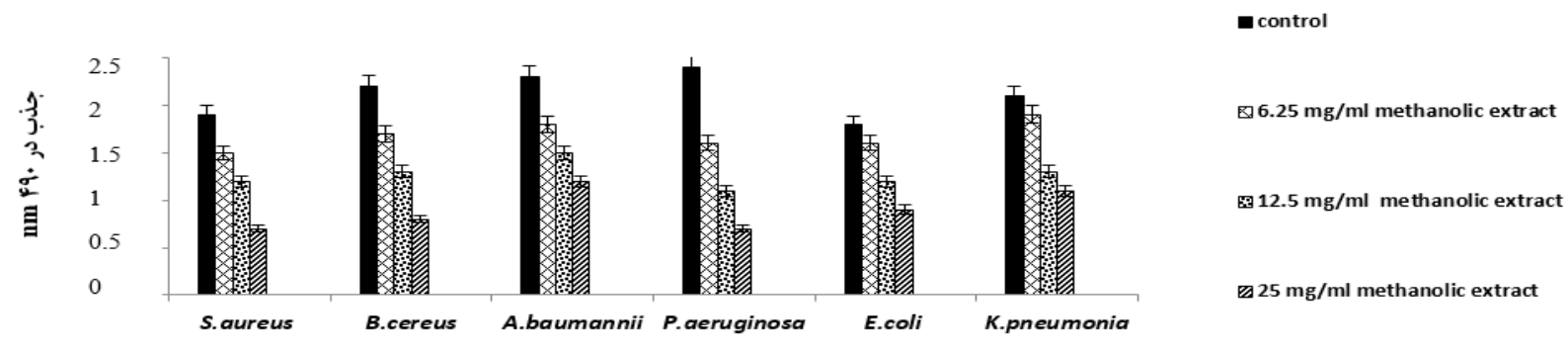

شكل F. مقايسة تأثير عصارة متانولى تركيب T.C.P بر آنزيم دهيدروزناز باكترىها

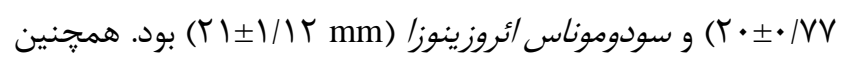
مقادير MBC و MIC براى عصارة تركيبى T.C.P بر باكترىهاى

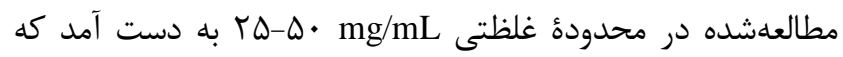

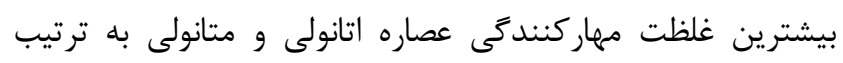

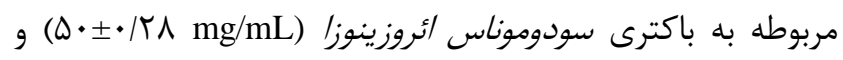

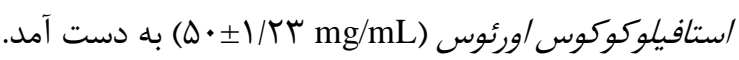

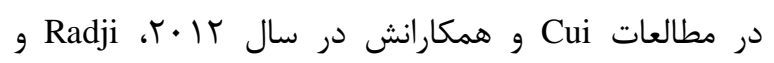

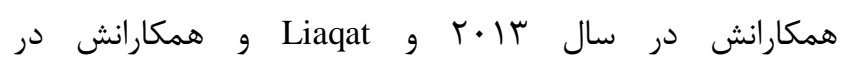

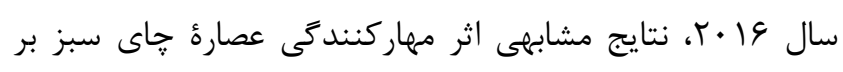

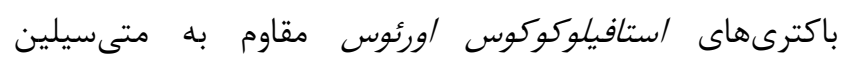
(Methicillin-resistant Staphylococcus aureus (MRSA)) Multi-drug resistant ( سودوموناس ائروزينوزا مقاوم به جند دارو (Pseldomona (Pseudomonas aeruginosa (MDR-P. aeruginosa) استافيلوكوكوس /ورئوس، باسيلوس سرئوس، سودوموناس /ئروزينوزا،

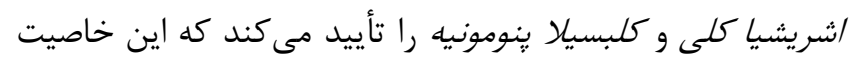

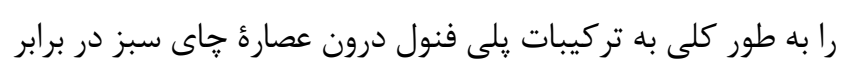

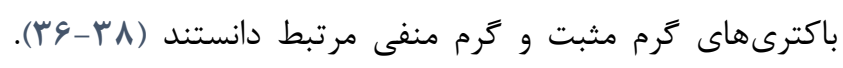

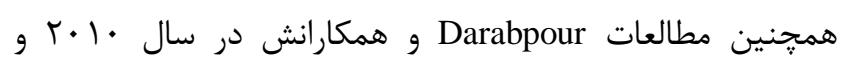
Hatano

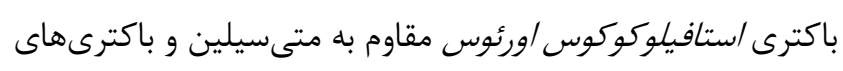
باسيلوس سرئوس، /ستافيلوكوكوس /ورئوس و /شريشيا كلى رألى را تأييد
بحث

امروزه يكى از دلايل اصلى ايجاد عفونت در انسان، مقاومت

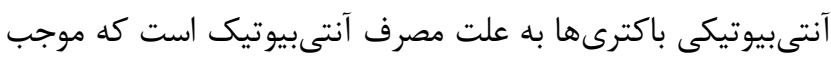
ظهور و گسترش سويههاى باكترى مقاوم به آنتىبيوتيك مي شوى شود.

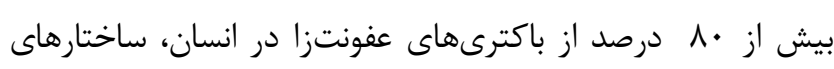

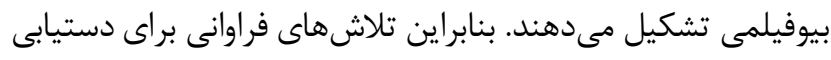

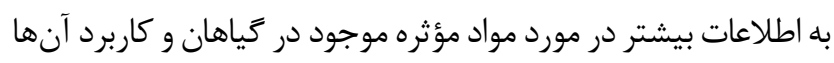

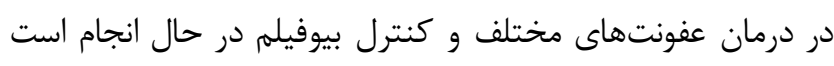

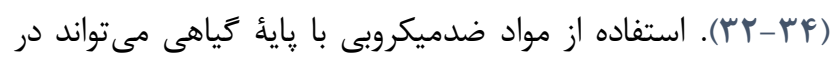

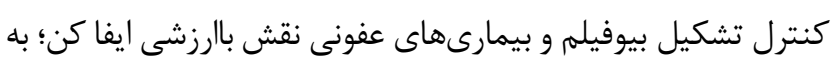

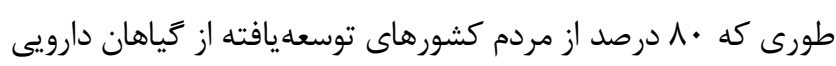

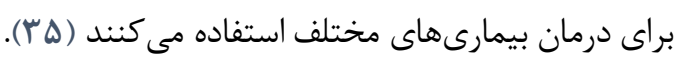

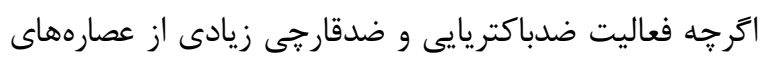

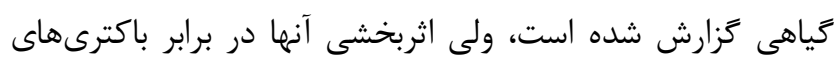

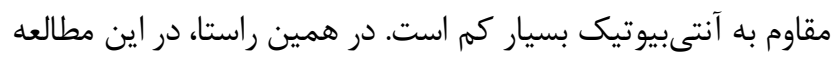

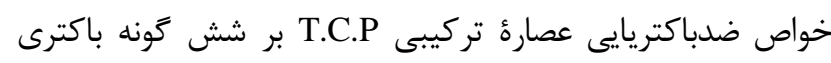

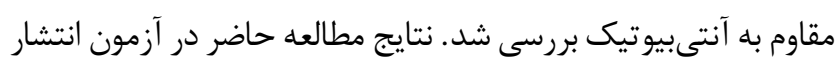
ديسك،MBC و MIC نشان مي Mدهد عصارة تركيبى T.C.P توانايى زيادى در جلوكيرى از رشد باكترىهاى مقاوم به آنتىبيوتيك دارد؛

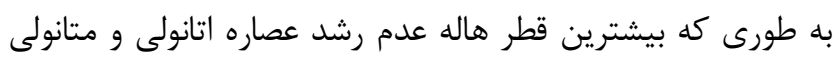

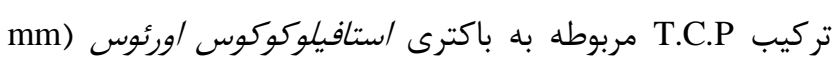


غلظت ارتباط دارد. توانايى عصارة اتانولى در مهار بيوفيلم بيشتر از

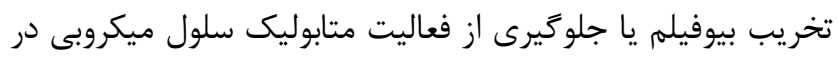

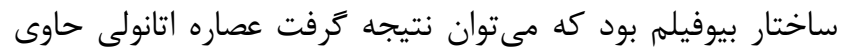

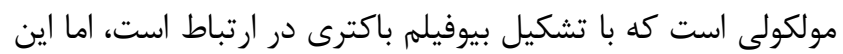

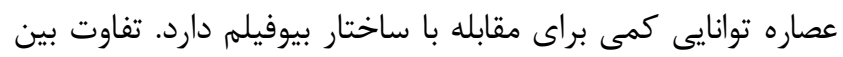

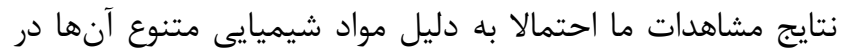

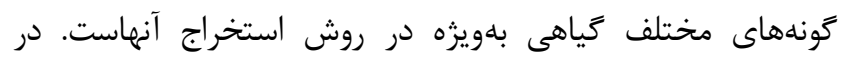

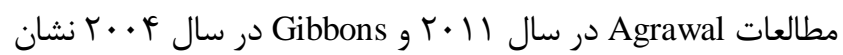
داده شد عصاره جاى سبز باعث مهار تشكيل بيوفيلم در باكترىهاى

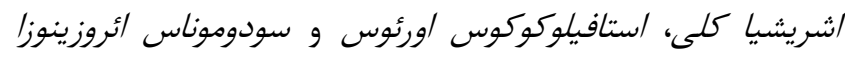

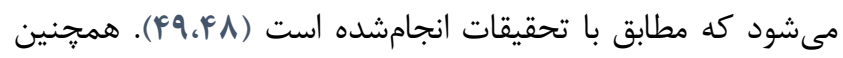

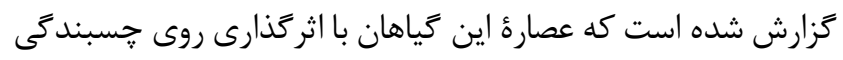

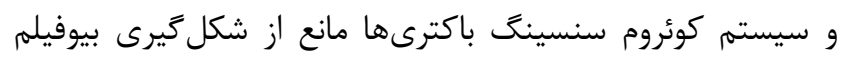

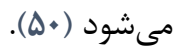

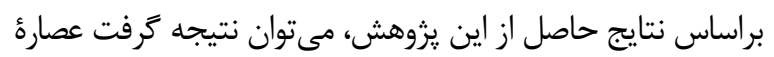

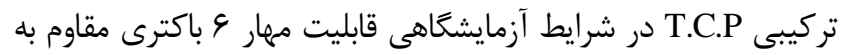

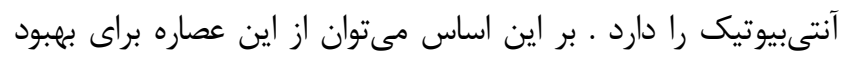

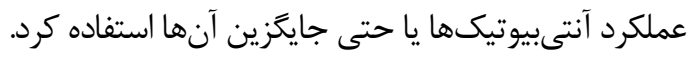

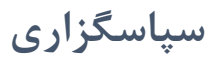

نويسندًان اين مقاله از معاونت يروهشى دانشخاه شهيد بارئ باهنر

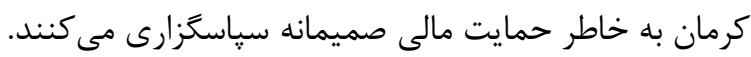

$$
\text { تعارض منافع }
$$
بين نويسندكان تعارض در منافع تزارش نشده است.

\section{References}

1. Mohsenipour Z, Hassanshahian M. Comparison of Antimicrobial Effects of Pomegranate Alcohol Extract on Single and Biofilm Form of Six Pathogenic Bacteria. Journal of Babol University of Medical Science. 2014; 17(1):77-84.

2. Mohsenipour Z, Hassanshahian, M. Antibacterial Activity of Euphorbia Hebecarpa Alcoholic Extracts Against Six Human Pathogenic Bacteria in Planktonic and Biofilm Forms. Jundishapur Journal of Microbiology. 2016; 9(6):e34701. [DOI:10.5812/jjm.34701] [PMID] [PMCID]

3. Sadeghian I, Hassanshahian, M, Sadeghian S, Jamali S. Antimicrobial Effects of Quercus Brantii Fruits on Bacterial Pathogens. Jundishapur Journal of

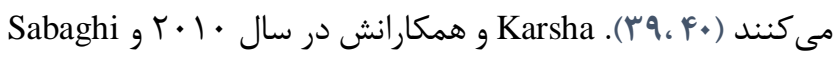

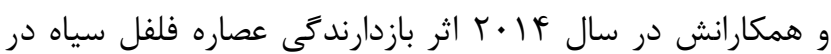
برابر باكترىهاى استافيلوكوكوس اورئوس مقاوم به آنتىبيوتيك، استافيلوكوكوس اورئوس، باسيلوس سرئوس، سودوموناس ائروزينوزا،

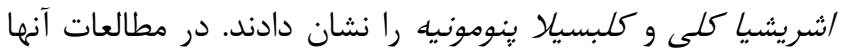

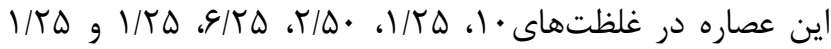
mg/mL بيشترين اثر بازدارندگى را داشت (F)،FY).

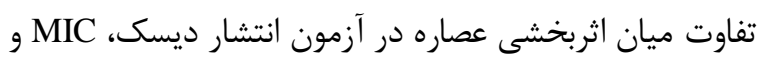

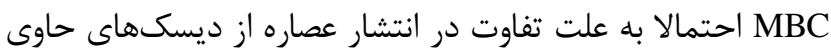

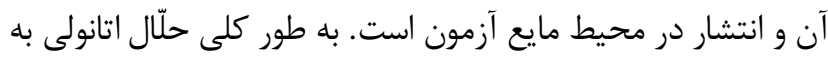
طور مؤثرترى نسبت به حلّال متانولى توانسته است با اجزا و مواد

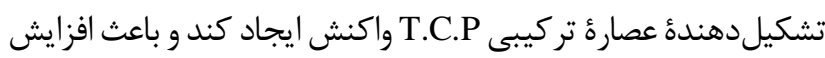
خروج مواد مؤثر از زياه و بالا رفتن غلظت اين مواد در عصاره اتانولى نسبت به عصاره متانولى T.C.P شود. اثرات ضدباكتريايى اين عصارة تركيبى ممكن است به خاطر تركيبات موجود در عصاره باشد كه ميكروار ₹انيسمها هر گز در معرض آن قرار نخرفتهاند. بنابراين هرگز فرصتى براى ايجاد مقاومت نداشتهاند. همجنين تركيبات شناختهشده

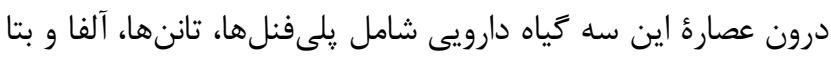
ييننها و غيره مىتواند باعث رسوب يروتئينهاى باكترى، مهار

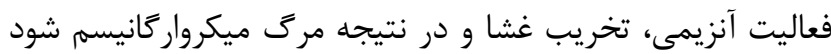

. (Fr-FV)

كياهان نقش مهمى در ازبينبردن شكل گيرى بيوفيلم باكترى -

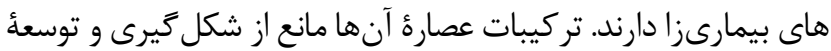
بيوفيلم مىشود. در مطالعهُ حاضر عصاره تركيبى T.C.P در مقابله با

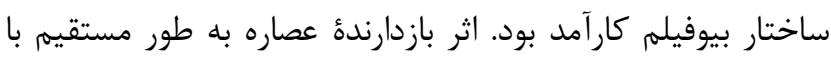

$5(3): 465-9$ [DOI:10.5812/ijm.3376]

4. Mohammadi M, Masoumipour F, Hassanshahian M, Jafarinasab T. Study the antibacterial and antibiofilm activity of Carum copticum against antibiotic-resistant bacteria in planktonic and biofilm forms. Microbial Pathogenesis. 2019; [DOI:10.1016/j.micpath.2019.02.002] [PMID]

5. Saeidi S, Amini Boroujeni N, Ahmadi $\mathrm{H}$, Hassanshahian M. Antibacterial Activity of Some Plant Extracts Against Extended- Spectrum BetaLactamase Producing Escherichia coli Isolates. Jundishapur Journal of Microbiology. 2015; 8(2):e15434. [DOI:10.5812/jjm.15434] [PMID] [PMCID]

6. Mohsenipour Z, Hassanshahian M. The Inhibitory Effect of Thymus Vulgaris Extracts on the Planktonic 
Form and Biofilm Structures of Six Human Pathogenic Bacteria. Avicenna Journal Phytomedicine. 2015; 5(4):309-17.

7. Sepehri Z, Javadian F, Khammari D, Hassanshahian M. Antifungal Effects of the Aqueous and Ethanolic Leaf Extracts of Echinophora Platyloba and Rosmarinus Officinalis. Current Medical Mycology. 2016; 2(1):16-25 [DOI:10.18869/acadpub.cmm.2.1.30] [PMID] [PMCID]

8. Mohsenipour Z, Hassanshahian M, Moradi M. Investigations of Antimicrobial Activity of Eucalyptus Camaldulensis Extracts Against Six Pathogenic Bacteria in Planktonic Form and Biofilm. Journal of Kerman University of Medical Science. 2015; 22(2):172-84.

9. Masoumipour F, Hassanshahian M, Jafarinasab T. Antimicrobial Activity of Combined Extracts of Trachyspermum, Thymus and Pistachio Against Some Pathogenic Bacteria. Journal of Kerman University of Medical Science. 2018; 25(2):153-63.

10. Savithramma N, Linga Rao M, Suhrulatha D. Screening of Medicinal Plants for Secondary Metabolites. Middle East Journal Science Research. 2011; 8(3):579-84

11. Hassanshahian M, Bayat Z, Saeidi S, Shiri Y. Antimicrobial Activity of Trachyspermum Ammi Essential Oil Against Human Bacterial. International Journal Advance Biological Biomed Research. 2014; 2(1):18-24.

12. Chakraborty B, Nath A, Saikia H, Sengupta M. Bactericidal Activity of Selected Medicinal Plants Against Multidrug Resistant Bacterial Strains From Clinical Isolates. Asian Pacific Journal of Tropical Medicine. 2014; 7:435-41. [DOI:10.1016/S19957645(14)60271-6]

13. Saeidi S, Shiri Y, Bokaeian M, Hassanshahian M. Antibacterial Activity of Essential Oil of Saturejahortensis Against Multi-Drug Resistant Bacteria. International Journal Enteric Pathogen. 2013; 2(2):1-4. [DOI:10.17795/ijep16349]

14. Weinstine RA. Controlling Antimicrobial Resistance in Hospitals: Infection Control and Use Of Antibiotics. Emerging Infectious Diseases. 2001; 7(2):188-92. [DOI:10.3201/eid0702.010206] [PMID]

15. Bokaeian M, Sheikh M, Hassanshahian M, Saeidi S, Sahraei S. The Antibacterial Activity of Silver Nanoparticles Produced in the Plant Sesamum Indicum Seed Extract: A Green Method Against Multi-Drug Resistant Escherichia Coli. International Journal Enteric Pathogen. 2014; 2(2):e17928. [DOI:10.17795/ijep17928]

16. Rezaie Keikhaie K, Ghorbani S, Hosseinzadeh Z, Hassanshahian M. Antimicrobial Activity of Methanol
Extract of Citrullus Colocynthis Against AntibioticResistant Staphylococcus Aureus. Advance Herbal Medicine 2017; 3(3):1-6.

17. Hassanshahian M, Khosravi F. Study the Antimicrobial Effects of Artemisia Santonica Extract on Some Pathogenic Bacteria. Advance Herbal Medicine .2015; 1(4):43-6.

18. Mohsenipour Z, Hassanshahian M. Antibacterial activity of Espand (Peganum Harmala) Alcoholic Extracts Against Six Pathogenic Bacteria in Planktonic and Biofilm Forms. Biological Journal Microorganism. 2016; 4(16):47-57. [DOI:10.5812/jjm.34701] [PMID] [PMCID]

19. Javadian F, Sepehri Z, Saeedi S, Hassanshahian M. Antifungal Effects of the Extract of the Withania Somnifera on Candida Albicans. Advance Herbal Medicine. 2016; 2(1):32-43.

20. Hamayeli H, Shoshtari A, Hassanshahian M, Askari M. Study the Antimicrobial Activity of Six Marine Sponges and Three Parts of Sea Anemone on Candida Albicans. Journal Coastal Life Medicine. 2016; 4(8):122-9. [DOI:10.12980/jclm.4.2016J6-76]

21. Mashhadi M, Fakhri J, Saeedi S, Hassanshahian M, Abkhoo A. Antimicrobial Effects of Medicinal Plants Collected in Zabol, Iran, on Pathogenic Food Pathogenic. Journal of Medical Bacteriology. 2016; 5(3):18-28.

22. Jahani Z, Hosseinzadeh F, Shahi Z, Shikhzadeh M, Hassanshahian M, Saeedi S. In Vitro Study of Antimicrobial Effects of Rosmarinus Officinalis and Glycyrrhiza Glabra Extracts Against Some Pathogens. Advance Herbal Medicine. 2016; 2(4):32-9.

23. Heydari F, Saeedi S, Hassanshahian M. Antibacterial Activity of Mentha Longifolia Against Salmonella Typhimurium. Advance Herbal Medicine. 2015; $1(3): 42-7$.

24. Mohsenipour Z, Hassanshahian M. Investigating the Effectiveness of Centaureacyanus Extracts on Planktonic Growth and Biofilm Structures of Six Pathogenic Bacteria. SSU Journals. 2014; 22(4):135870.

25. Mohsenipour Z, Hassanshahian M. Inhibitory Effects of Tamarix Hispida Extracts on Planktonic Form and Biofilm Formation of Six Pathogenic Bacteria. Biological Journal Microbiology. 2015; 4(13):25-36.

26. Sepehri Z, Hassanshahian M, Shahi Z, Nasiri A, Baigi S. Antibacterial Effect of Ethanol Extract of Camellia Sinensis L Against Escherichia Coli. Asian Pacific Journal Microbiology Research. 2014; 2(1):6-8.

27. Rezaie Keikhaie K, Bagheri G, Hassanshahian M, Saeidi S. Antimicrobial Effects of Zataria Multiflora Essential Oils on Acinetobacter Strains Isolated From 


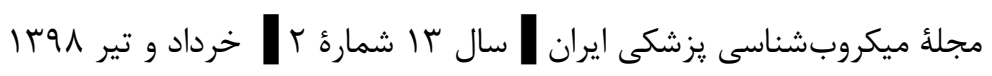

Clinical Specimens. Journal Herbal Drug. 2018; 8(4):251-6. [DOI:10.14196/JHD.2018.251]

28. Jabra Rizk MA, Meiller TF, James CE, Shirtliff ME. Effect of Farnesol on Staphylococcus Aureus Biofilm Formation and Antimicrobial Susceptibility. Antimicrobial Agents and Chemotherapy. 2006; 50(4):1463-9. [DOI:10.1128/AAC.50.4.14631469.2006] [PMID] [PMCID]

29. Sandasi M. The Effect of Plant Extraction on Microbial Biofilm Formation and Development [Master thesis]. Pretoria: Tshwane University of Technology; 2008.

30. Ramage G, López-Rib JL. Techniques for Antifungal Susceptibility Testing of Candida Albicans Biofilms. In: Ernest EJ, Rogers PD, editors. Antifungal Agents. Totowa, New Jersey: Humana Press; 2005.

31. Høiby N, Bjarnsholt T, Givskov M, Molin S, Ciofu O. Antibiotic Resistance of Bacterial Biofilms. International Journal of Antimicrobial Agents. 2010; 35(4):322-32.

[DOI:10.1016/j.ijantimicag.2009.12.011] [PMID]

32. Stanisavljević I, Stojičević S, Veličković D, Veljković V, Lazić M. Antioxidant and Antimicrobial Activities of Echinacea (Echinacea Purpurea L.) Extracts Obtained by Classical and Ultrasound Extraction. Chinese Journal of Chemical Engineering. 2009; 17(3):478-83. [DOI:10.1016/S1004-9541(08)602347]

33. Hoiby N, Bjarnsholt T, Givskov M, Molin S, Ciofu O. Antibiotic Resistance of Bacterial Biofilms. International Journal of Antimicrobial Agents. 2010; 35:322-32. [DOI:10.1016/j.ijantimicag.2009.12.011] [PMID]

34. Ghotaslou R, Salahi B. Effects of Oxygen on In-Vitro Biofilm Formation and Antimicrobial Resistance of Pseudomonas Aeruginosae. Pharmaceutical Sciences. 2013; 19(3):96.

35. Nascimento GG, Locatelli J, Freitas PC, Silva GL. Antibacterial Activity of Plant Extracts and Phytochemicals on Antibiotic-Resistant Bacteria. Brazilian Journal of Microbiology. 2000; 31(4):24756. [DOI:10.1590/S1517-83822000000400003]

36. Cui Y, Oh YJ, Lim J, Youn M, Lee I, Pak HK, et al. AFM Study of the Differential Inhibitory Effects of the Green Tea Polyphenol Epigallocatechin-3-Gallate (Egcg) Against Gram-Positive and Gram-Negative Bacteria. Food Microbiology. 2012; 29(1):80-7. [DOI:10.1016/j.fm.2011.08.019] [PMID]

37. Radji M, Agustama RA, Elya B, Tjampakasari CR. Antimicrobial Activity of Green Tea Extract Against Isolates of Methicillin-Resistant Staphylococcus Aureus and Multi-Drug Resistant Pseudomonas Aeruginosa. Asian Pacific Journal of Tropical
Biomedicine. 2013; 3(8):663-7. [DOI:10.1016/S22211691(13)60133-1]

38. Liaqat I, Pervaiz Q, Bukhsh SJ, Ahmed SI, Jahan N. Investigation of Bactericidal Effects of Medicinal Plant Extracts on Clinical Isolates and Monitoring Their Biofilm Forming Potential. Pakistan Veterinary Journal. 2016; 36(2):159-64.

39. Darabpour E, Motamedi H, Nejad SM. Antimicrobial Properties of Teucrium Polium Against Some Clinical Pathogens. Asian Pacific Journal of Tropical Medicine. 2010; 3(2):124-7. [DOI:10.1016/S19957645(10)60050-8]

40. Hatano T, Kusuda M, Inada K, Ogawa TO, Shiota S, Tsuchiya T, et al. Effects of Tannins and Related Polyphenols on Methicillin-Resistant Staphylococcus Aureus. Phytochemistry. 2005; 66(17):2047-55. [DOI:10.1016/j.phytochem.2005.01.013] [PMID]

41. Karsha PV, Lakshmi OB. Antibacterial Activity of Black Pepper (Piper Nigrum Linn.) With Special Reference to Its Mode of Action on Bacteria. Indian Journal of Natural Products and Resources. 2010; 1(2):213-15.

42. Sabbagh SK, Saeedi S, Dehbashi Z, Naeeini MM. Antimicrobial Activity of Ethanolic Extract of Black Pepper (Piper Nigrum) and March (Peganum Harmala) Against Antibiotic-resistant of Staphylococcus Aureus Strains. Bimonthly Journal of Sabzevar University of Medical Sciences. 2014; 22(5).

43. Erasto P, Bojase MoletaG, Majinda RRT. Antimicrobial and Antioxidant Flavonoids From the Roots Wood of Bolusathusspesiosus. Phytochem. 2004; 65:875-80 [DOI:10.1016/j.phytochem.2004.02.011] [PMID]

44. Viljoen A, Van Vuuren S, Ernst E, Klepser M, Demirci B, Başer H, et al. Osmitopsis Asteriscoides (Asteraceae)-the Antimicrobial Activity and Essential Oil Composition of A Cape-Dutch Remedy. Journal of Ethnopharmacology. 2003; $\quad 88(2): 137-43$. [DOI:10.1016/S0378-8741(03)00191-0]

45. Kali A. Antibiotics and Bioactive Natural Products in Treatment of Methicillin Resistant Staphylococcus Aureus: A Brief Review. Pharmacognosy Reviews. 2015; 9(17):29. [DOI:10.4103/0973-7847.156329] [PMID] [PMCID]

46. Thakur P, Chawla R, Chakotiya AS, Tanwar A, Goel R, Narula A, et al. Camellia Sinensis Ameliorates the Efficacy of Last Line Antibiotics Against Carbapenem Resistant Escherichia Coli. Phytotherapy Research. 2016; 30(2):314-22. [DOI:10.1002/ptr.5535] [PMID]

47. Farooqui A, Khan A, Borghetto I, Kazmi SU, Rubino S, Paglietti B. Synergistic Antimicrobial Activity of Camellia Sinensis and Juglans Regia Against Multidrug-Resistant Bacteria. PloS One. 2015; 10(2):e0118431. 
[DOI:10.1371/journal.pone.0118431]

[PMID] [PMCID]

48. Agrawal I. Susceptibility of Bacterial Biofilms Against Some Leaf Extracts. Plant Sciences Feed. 2011; 1(5):69-73.

49. Gibbons S. Anti-Staphylococcal Plant Natural Products. Natural Product Reports. 2004; 21(2):26377. [DOI:10.1039/b212695h] [PMID]

50. Simoes M, Bennett RN, Rosa EA. Understanding Antimicrobial Activities of Phytochemicals Against Multidrug Resistant Bacteria and Biofilms. Natural Product Reports. 2009; 26(6):746-57. [DOI:10.1039/b821648g] [PMID] 